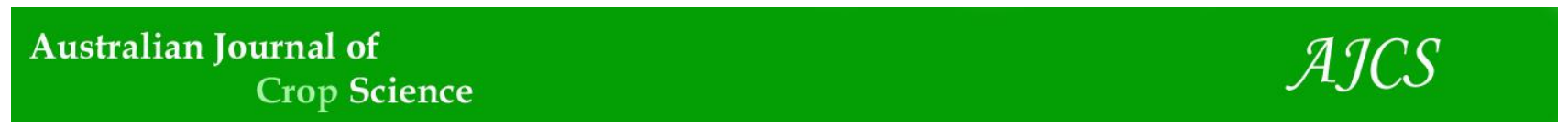

AJCS 13(10):1594-1599 (2019)

ISSN:1835-2707

doi: 10.21475/ajcs.19.13.10.p1803

\title{
Nutrient uptake in 'Venus' grape vine grafted onto different rootstocks during two growing seasons
}

\author{
Marco Antonio Tecchio ${ }^{1}$, Marlon Jocimar Rodrigues da Silva ${ }^{1}$, Daniel Callili ${ }^{1}$, Giovanni Marcello De Angeli \\ Gilli Cóser ${ }^{1}$, Dávilla Alessandra da Silva Alves ${ }^{1}$, Francisco José Domingues Neto ${ }^{1}$, Mara Fernandes Moura ${ }^{2}$ \\ ${ }^{1}$ São Paulo State University (Unesp), School of Agriculture, Botucatu, José Barbosa de Barros Street, 18610-307, \\ Botucatu, São Paulo, Brazil \\ ${ }^{2}$ Fruit APTA Center (IAC), Luiz Pereira do Santos Street, 1500, 13214-820, Jundiaí, São Paulo, Brazil
}

*Corresponding author: daniel_callili@hotmail.com

\begin{abstract}
The current study aimed to assess the influence of the 'IAC 766', 'IAC 572', 'IAC 313' and 'IAC 571-6' rootstocks on nutrient uptake of 'Venus' grape vine by pruning branches and harvesting clusters during two consecutive grape growing seasons. The experiment was conducted in Votuporanga, state of Sao Paulo. Treatments consisted of the variety 'Venus' grafted onto four rootstocks during two growing seasons (2013 and 2014). The rootstocks evaluated were 'IAC 766', 'IAC 572', 'IAC 313' and 'IAC 571-6'. We sampled the grape branches at pruning and their clusters at harvest time. The macro and micronutrient contents in both branches and clusters were analyzed. Nutrient uptake and removal were separately estimated in pruned branches and harvested clusters by uptake nutrient sum. Results indicated great nutrient uptake means in 'IAC 572' and 'IAC 766' during both seasons. Moreover, total removal uptake showed the following order $\mathrm{K}>\mathrm{N}>\mathrm{Ca}>\mathrm{P}>\mathrm{Mg}>\mathrm{S}>\mathrm{Mn}>\mathrm{Fe}>\mathrm{Zn}>\mathrm{B}>\mathrm{Cu}$ in pruned branches and harvested clusters.
\end{abstract}

Keywords: Vitis, mineral nutrition, total extraction, macronutrients, micronutrients.

Introduction

The State of São Paulo is in a prominent position in the Brazilian viticulture scenario. In 2017, production was equivalent to $133,118 \mathrm{t}$ of grape in the state of Sao Paulo, where is the third largest grape producer for direct consumption in Brazil (Agrianual, 2018). The Northwest region of this state plays an important role, as the Brazilian grape center. From 2008 and 2015, there was a significant increase in non-vinifera grapes (Vitis labrusca and hybrids) consumption as table grape in this area, e.g. 'Niagara Rosada' that presented an increase of $153 \%$ in production during the period (IEA, 2016). With regards to non-vinifera grapes, the blue-black seedless 'Venus' becomes an alternative for winegrowers; although it is most often consumed as a table grape.

The 'Venus' grape was developed by Moore and Brown in 1977, through the University of Arkansas table grape breeding program, United States. In 1984, Brazilian Agricultural Research Corporation (Embrapa Grape and Wine) introduced 'Venus' grape in the country. This hybrid tends to be vigorous and productive. 'Venus' is a mostly seedless, dark-coloured grape that has a foxy, Muscat flavour. It has cylindrical clusters that can weight from 200 to $400 \mathrm{~g}$ (Camargo and Mandelli, 1993). Although, it has been available to Brazilian producers for over 30 years, 'Venus' grape has not been fully explored in Brazil, since there are few growing areas in the country. There is a paucity of literature on this cultivar growing potential, especially in the Northwest region of São Paulo state.

For grape vine, the amount of nutrients extracted by clusters and branches is crucial, since is possible to evaluate the sequences of accumulation in descending order for macroand micronutrients, aiding in fertilization of plants. Several factors influence nutrients uptake in grape vine, such as scion and rootstock variations (Tecchio et al., 2011). Moreover, mineral analysis is the most appropriate method to estimate patterns of nutrient absorption and use by plants from biomass compositional analysis (Weinbaum et al., 2001).

Although, rootstock is known for its vigor, several studies have shown that rootstocks differ in their effect on water and nutrient absorption capacity in the grafted variety, since there is selectivity in ion movement in soil and root absorption, according to each variety (Tecchio et al., 2011). Each rootstocks may interact differently with grape vine's fruits phenology, degree-day accumulation, yield, quality (Motta et al., 2009; Rizk-Alla et al., 2011; Jogaiah et al., 2013; Tecchio et al., 2013; Tofanelli et al., 2011); plants physiology (Cookson and Ollat, 2013); soaked and saline soils tolerance (Jogaiah et al., 2014); plant resistance to drought (Serra et al., 2014); and disease resistance (Billones-Baaijen et al., 2014, Murolo and Romanazzi, 2014). Besides the combination of rootstocks and canopy conductance can 
affect water and nutrient uptake in grape vines (Bavaresco and Lovisolo, 2000).

Literature has already correlated high nutrients uptake with increase in plant yield. According to Rosecrance et al. (1996), the higher the yield, the higher the nutrients removal from crop will be, especially potassium and nitrogen. Fruits are the main metabolic reservoir of trees, which can reduce the growth of plant's vegetative and radicular system (Heim et al., 1979; Rosecrance et al., 1996; Weinbaum et al., 1994).

In Videira, state of Santa Catarina, Bettoni et al. (2013) assessed the nutrients extraction and export by cv. Cabernet Sauvignon grapevine grafted on 'VR 043-43' and 'Paulsen 1103' rootstocks, they only noticed significant differences for phosphorus content, with values of 3.87 and $2.36 \mathrm{~g} \mathrm{Kg}^{-1}$ respectively. Faria et al. (2004) also obtained similar values for cv. Cabernet Sauvignon, as they observed the $P$ content of 1.33 and $4.13 \mathrm{mg} \mathrm{kg}^{-1}$ in the petiole during full bloom and harvest time respectively. According to them, $\mathrm{K}$ was the only one that presented a significant difference for 'VR 043-43' and 'Paulsen 1103' rootstocks among the nutrients exported to berries, with contents of 2048 and $1829 \mathrm{Kg} \mathrm{ha}^{-1}$, respectively. Sato et al. (2016) assessed the yield and nutrients uptake of 'Isabel Precoce' grape vines grafted on 'Paulsen 1103' and 'VR 043-43' rootstocks in the region of Marialva, state of Parana, yielding between 9.9 and $16.6 \mathrm{t}$ $\mathrm{ha}^{-1}$, respectively. The amounts of $\mathrm{N}, \mathrm{P}, \mathrm{K}, \mathrm{Ca}$ and $\mathrm{Mg}$ were, respectively, of $64.9,19.0,156.9,45.8$ and $12.66 \mathrm{~kg} \mathrm{ha}^{-1}$ when grafted on 'Paulsen 1103'; and 112.8, 29.3, 260.8, 82.3 and $26.0 \mathrm{~kg} \mathrm{ha}^{-1}$ when grafted on 'VR 043-43'.

During a nutritional survey in Jundiai, state of Sao Paulo, Tecchio et al. (2007) concluded that 'Niagara Rosada' grafted on '106-8 Mgt' rootstocks presented high levels of $P$, Fe and $\mathrm{Zn}$ in the clusters, whereas on 'IAC 766' rootstocks had a high level of $\mathrm{Mn}$. On both rootstocks, 'Niagara Rosada' presented the following descending order of nutrient accumulation within the clusters: $\mathrm{K}>\mathrm{N}>\mathrm{P}>\mathrm{Ca}>\mathrm{S}>\mathrm{Mg}>\mathrm{B}$ $>\mathrm{Fe}>\mathrm{Mn}>\mathrm{Cu}>\mathrm{Zn}$.

Several studies are available in literature on nutrients extraction from 'Niagara Rosada', but not on cv. 'Venus' grape vine. Therefore, the current study aimed to assess the influence of the 'IAC 766', 'IAC 572', 'IAC 313' and 'IAC 571$6^{\prime}$ rootstocks on nutrient uptake in 'Venus' grape vine by pruning branches and harvesting clusters during two consecutive grape growing seasons.

\section{Results and discussion}

\section{Yield components}

For yield, there was no significant interaction between rootstocks and growing seasons for clusters and branches dry mass that were removed by pruning 'Venus' grape vines. However, there were only isolated effects on rootstocks (Table 1); thus, we considered the average obtained during two assessment seasons.

The highest yield and cluster dry mass were obtained in 'IAC 572 ' rootstock, with values of 17,1 ton ha-1 and $3037 \mathrm{~kg} \mathrm{ha}^{-1}$, respectively (Table 1 ). There are a few studies examined the effect of rootstocks on cv. 'Venus', since most of them are related to other grape vine cultivars. With regards to yield per plant, Terra et al. (2003) obtained similar values, that is 3.19 to $3.33 \mathrm{~kg}$ in 'Niagara Rosada' grafted onto 'IAC 313', 'Ripária do Traviú', 'IAC 766' and 'IAC 572' rootstocks. While, Mota et al. (2009) obtained a higher yield in grape vines grafted on 'IAC 572' rootstocks compared to 'IAC 766'. These data show that scion and rootstock combination in grape vines depend on soil and climatic conditions of each region. 'IAC 572' and 'IAC 766' rootstocks increased branch dry mass in 'Venus' grape vines, with values of 1608 and $1283 \mathrm{~kg} \mathrm{ha}^{-1}$, respectively (Table 1 ). These results are like those obtained by Tecchio et al. (2011) in cv. Niagara Rosada, as obtained an increase in branch dry mass by using 'IAC 572' and 'IAC 766' rootstocks, compared to 'IAC 571-6'. The more vigorous the rootstocks are, the greater their capacity of water-nutrients absorption and translocation; consequently, contributing for canopy development. However, rootstock vigor is not always related to high yield (Pauletto et al., 2001).

\section{Nutrient uptake by pruning branches and harvesting clusters, separately}

There was an isolated effect of rootstocks and yield cycles on nutrient content in 'Venus' grape vines branches and clusters, except for P, Fe and Zn contents in branch's samples (Tables 2 and 3). Nevertheless, differences in nutrient content of grape vine branches and clusters could be found to the genetics of rootstock and their vigor; such changes have been reported by several authors (Albuquerque and Dechen, 2000; Tecchio et al., 2007; Miele et al. 2009; Tecchio et al., 2011).

In branches of 'Venus' grape vines grafted onto different rootstocks during two growing seasons, results indicated an average of $9.9 \mathrm{~g} \mathrm{~kg}^{-1} \mathrm{~N}, 1.6 \mathrm{~g} \mathrm{~kg}^{-1} \mathrm{P}, 6.6 \mathrm{~g} \mathrm{~kg}^{-1} \mathrm{~K}, 10.4 \mathrm{~g} \mathrm{~kg}^{-1} \mathrm{Ca}$, $2.3 \mathrm{~g} \mathrm{~kg}^{-1} \mathrm{Mg}$ and $1.0 \mathrm{~g} \mathrm{~kg}^{-1} \mathrm{~S}$. Furthermore, same sample presented the averages of $15.9 \mathrm{mg} \mathrm{kg}^{-1} \mathrm{~B}, 30.4 \mathrm{mg} \mathrm{kg}^{-1} \mathrm{Cu}$, $62.4 \mathrm{mg} \mathrm{kg}^{-1} \mathrm{Fe}, 410.2 \mathrm{mg} \mathrm{kg}^{-1} \mathrm{Mn}$ and $72.14 \mathrm{mg} \mathrm{kg}^{-1} \mathrm{Zn}$. The values of $\mathrm{N}, \mathrm{P}, \mathrm{K}, \mathrm{Ca}, \mathrm{Mg}$ and $\mathrm{S}$ in the current study were 20 to $25 \%$ higher than the ones obtained by Tecchio et al. (2011 and 2014), while analyzed nutrient content of 'Niagara Rosada' grape vines in Votuporanga and Jundiai, respectively.

In branch's samples, high $\mathrm{N}, \mathrm{Ca}$ and $\mathrm{Mg}$ contents were observed in 'IAC $313^{\prime}$ ' and 'IAC 766 ' rootstocks. Besides that, 'IAC 766', 'IAC 572' and 'IAC 571-6' rootstocks obtained high $S$ content. An increase in $B$ and $C u$ contents were performed in 'IAC 313', 'IAC 571-6' and 'IAC 766' rootstocks; in addition to high $\mathrm{Mn}$ content in 'IAC 313' and 'IAC 766' rootstocks. The 'IAC 313' rootstock obtained an increase in macro and micronutrient contents in branches, due to the low accumulation of branch dry mass (Table 1). Tecchio et al. (2011) obtained high levels of $\mathrm{N}$ and $\mathrm{Mg}$, and low $\mathrm{K}$ content in branches of 'Niagara Rosada' grape vines grafted on 'IAC 766 ' rootstock compared to 'IAC 313'.

On clusters samples of 'Venus' grape vine grafted onto different rootstocks (Table 3), results indicated an average of $6.3 \mathrm{~g} \mathrm{~kg}^{-1} \mathrm{~N}, 1.2 \mathrm{~g} \mathrm{~kg}^{-1} \mathrm{P}, 12.5 \mathrm{~g} \mathrm{~kg}^{-1} \mathrm{~K}, 3.6 \mathrm{~g} \mathrm{~kg}^{-1} \mathrm{Ca}, 0.8 \mathrm{~g} \mathrm{~kg}^{-1}$ $\mathrm{Mg}$ and $0.5 \mathrm{~g} \mathrm{~kg}^{-1} \mathrm{~S}$. On the same samples, the contents of $11.6 \mathrm{mg} \mathrm{kg}^{-1} \mathrm{~B}, 1.5 \mathrm{mg} \mathrm{kg}^{-1} \mathrm{Cu}, 26.8 \mathrm{mg} \mathrm{kg}^{-1} \mathrm{Fe}, 40.4 \mathrm{mg} \mathrm{kg}^{-1}$ $\mathrm{Mn}$ and $2.5 \mathrm{mg} \mathrm{kg}^{-1} \mathrm{Zn}$. The average levels of $\mathrm{N}$ and $\mathrm{K}$ were lower and those of $\mathrm{Ca}$ and $\mathrm{Mg}$ higher than those obtained by Tecchio et al. (2011 and 2014), while assessed 'Niagara Rosada' grape vines grown in Votuporanga and Jundiai, respectively. Nevertheless, the nutrient contents differences in branches and clusters are mainly due to soil fertility and cultivars variation.

Regarding nutrient contents in clusters (Table 3 ), the highest $\mathrm{N}, \mathrm{K}$ and $\mathrm{Zn}$ contents were obtained in 'Venus' grape vines grafted on 'IAC 313' and 'IAC 572' rootstocks; the highest $P$ content in 'IAC 766' rootstock; the highest contents of $\mathrm{Ca}$, $\mathrm{Mg}, \mathrm{S}$ and $\mathrm{Fe}$ found in 'IAC 766' rootstock; the highest content of B in 'IAC 313' rootstocks and CU in 'IAC 572' and 
Table 1. Yield, cluster and branch dry mass removed by pruning 'Venus' grape vine grafted onto different rootstocks during two growing seasons.

\begin{tabular}{llll}
\hline Rootstocks & $\begin{array}{l}\text { Yield } \\
\text { (ton ha-1) }\end{array}$ & $\begin{array}{l}\text { Cluster dry mass } \\
\left(\mathrm{kg} \mathrm{ha}^{-1}\right)\end{array}$ & $\begin{array}{l}\text { Branch dry mass } \\
\left(\mathrm{kg} \mathrm{ha}^{-1}\right)\end{array}$ \\
\hline 'IAC 313' & $6.6 \mathrm{C}$ & $1238 \mathrm{~B}$ & $716.4 \mathrm{~B}$ \\
'IAC 572' & $17.1 \mathrm{~A}$ & $3037 \mathrm{~A}$ & $1608.3 \mathrm{~A}$ \\
'IAC 571-6' & $9.4 \mathrm{BC}$ & $1703 \mathrm{~B}$ & $831.3 \mathrm{~B}$ \\
'IAC 766' & $11.6 \mathrm{~B}$ & $2082 \mathrm{~B}$ & $1283.9 \mathrm{~A}$ \\
\hline Season & & & \\
\hline 2013 & 10.7 & 1916.9 & 1055.9 \\
2014 & 11.7 & 2113.0 & 1164.1 \\
\hline Average & 11.2 & 2014.9 & 1110.0 \\
\hline CV 1(\%) & 40.8 & 49.5 & 38.2 \\
CV 2 (\%) & 36.0 & 35.6 & 17.2 \\
\hline Different letters within a row for each factor (rootstock and growing season) indicate a significant difference according to Tukey's test $(p<0.05)$
\end{tabular}

Table 2. Macro and micronutrient contents in branch samples removed by pruning of 'Venus' grape vine grafted onto different rootstocks during two growing seasons.

\begin{tabular}{|c|c|c|c|c|c|c|c|c|c|c|c|}
\hline & $\mathrm{N}$ & $\mathrm{K}$ & $P$ & $\mathrm{Ca}$ & $\mathrm{Mg}$ & $S$ & B & $\mathrm{Cu}$ & $\mathrm{Fe}$ & $\mathrm{Mn}$ & $\mathrm{Zn}$ \\
\hline Rootstocks & ---------- & ---------. & $\left(\mathrm{g} \mathrm{kg}^{-1}\right)$ & - & ----- & & ------- & ------ $(r$ & $\left.\mathrm{kg}^{-1}\right)---$ & ------------- & \\
\hline ‘IAC 313’ & $10.0 \mathrm{ab}$ & $8.2 \mathrm{a}$ & 1.6 & $11.5 \mathrm{a}$ & $2.4 \mathrm{a}$ & $1.0 \mathrm{ab}$ & $17 a$ & $29 a b$ & 58 & $486 a$ & 70 \\
\hline ‘IAC 572’ & 9.7 bc & $6.6 \mathrm{~b}$ & 1.6 & $9.8 \mathrm{~b}$ & $2.1 \mathrm{~b}$ & $1.1 \mathrm{a}$ & $14 \mathrm{~b}$ & $26 \mathrm{~b}$ & 60 & $341 \mathrm{~b}$ & 65 \\
\hline ‘IAC 571-6’ & $9.4 \mathrm{c}$ & $6.2 b c$ & 1.6 & $10.1 \mathrm{~b}$ & $2.2 \mathrm{~b}$ & $1.0 \mathrm{ab}$ & $16 \mathrm{a}$ & $37 a$ & 69 & $453 a$ & 79 \\
\hline ‘IAC 766’ & $10.3 \mathrm{a}$ & $5.5 \mathrm{c}$ & 1.8 & $10.4 \mathrm{ab}$ & $2.4 \mathrm{a}$ & $1.0 \mathrm{~b}$ & $17 a$ & $30 a b$ & 63 & $361 b$ & 74 \\
\hline \multicolumn{12}{|l|}{ Season } \\
\hline 2013 & $9.7 \mathrm{~b}$ & $6.3 \mathrm{~b}$ & $1.5 \mathrm{~b}$ & 10.5 & $2.4 \mathrm{a}$ & $0.9 \mathrm{~b}$ & $20.7 a$ & $38.2 \mathrm{a}$ & $86.1 \mathrm{a}$ & $374.8 \mathrm{~b}$ & $90.4 \mathrm{a}$ \\
\hline 2014 & $10.1 \mathrm{a}$ & $6.9 \mathrm{a}$ & $1.8 \mathrm{a}$ & 10.4 & $2.1 \mathrm{~b}$ & $1.1 \mathrm{a}$ & $11.0 \mathrm{~b}$ & $22.6 \mathrm{~b}$ & $38.7 \mathrm{~b}$ & $445.5 \mathrm{a}$ & $53.7 \mathrm{~b}$ \\
\hline Average & 9.9 & 6.6 & 1.6 & 10.4 & 2.3 & 1.0 & 15.9 & 30.4 & 62.4 & 410.2 & 72.1 \\
\hline CV 1 (\%) & 6.2 & 16.9 & 16.9 & 13.4 & 11.4 & 10.3 & 9.9 & 40.6 & 24.7 & 21.4 & 27.4 \\
\hline CV 2 (\%) & 6.6 & 13.7 & 10.3 & 13.9 & 12.0 & 10.0 & 11.5 & 38.8 & 20.2 & 21.2 & 25.6 \\
\hline
\end{tabular}

Different letters within a row for each factor (rootstock and growing season) indicate a significant difference according to Tukey's test $(p<0.05)$.

Table 3. Macro and micronutrient contents in cluster samples of 'Venus' grape vine grafted onto different rootstocks during two growing seasons.

\begin{tabular}{|c|c|c|c|c|c|c|c|c|c|c|c|}
\hline \multirow[b]{2}{*}{ Rootstocks } & $\mathrm{N}$ & $\mathrm{K}$ & $P$ & $\mathrm{Ca}$ & $\mathrm{Mg}$ & $\mathrm{S}$ & B & $\mathrm{Cu}$ & $\mathrm{Fe}$ & $\mathrm{Mn}$ & $\mathrm{Zn}$ \\
\hline & \multicolumn{6}{|c|}{ - } & \multicolumn{5}{|c|}{ - } \\
\hline 'IAC 313' & $6.4 \mathrm{ab}$ & $14.1 \mathrm{a}$ & $1.1 \mathrm{~b}$ & $2.4 \mathrm{bc}$ & $0.7 \mathrm{~b}$ & $0.5 \mathrm{~b}$ & $15 \mathrm{a}$ & $0.6 \mathrm{c}$ & $23 \mathrm{~b}$ & $40 a b$ & $2.6 a b$ \\
\hline 'IAC 572’ & $6.7 \mathrm{a}$ & $15.1 \mathrm{a}$ & $1.0 \mathrm{~b}$ & $2.0 \mathrm{c}$ & $0.6 \mathrm{~b}$ & $0.5 \mathrm{~b}$ & $10 \mathrm{~b}$ & $2.2 \mathrm{a}$ & $25 \mathrm{~b}$ & $33 \mathrm{~b}$ & $2.8 \mathrm{a}$ \\
\hline ‘IAC 571-6’ & $6.0 \mathrm{~b}$ & $11.9 \mathrm{~b}$ & $1.1 \mathrm{~b}$ & $3.7 \mathrm{~b}$ & $0.7 \mathrm{~b}$ & $0.5 b$ & $10 \mathrm{~b}$ & $2.0 \mathrm{a}$ & $28 a b$ & $44 a$ & $2.4 \mathrm{~b}$ \\
\hline 'IAC 766’ & $6.2 b$ & $9.0 \mathrm{c}$ & $1.7 \mathrm{a}$ & $6.2 \mathrm{a}$ & $1.0 \mathrm{a}$ & $0.6 \mathrm{a}$ & $11 \mathrm{~b}$ & $1.2 \mathrm{~b}$ & $32 \mathrm{a}$ & $45 \mathrm{a}$ & $2.3 \mathrm{~b}$ \\
\hline \multicolumn{12}{|l|}{ Season } \\
\hline 2013 & $6.9 \mathrm{a}$ & $12.7 \mathrm{a}$ & $1.6 \mathrm{a}$ & $5.1 \mathrm{a}$ & $0.9 a$ & $0.7 a$ & $12.5 \mathrm{a}$ & $1.7 \mathrm{a}$ & $32.2 \mathrm{a}$ & $49.6 \mathrm{a}$ & $2.6 \mathrm{a}$ \\
\hline 2014 & $5.7 b$ & $12.3 \mathrm{a}$ & $0.9 \mathrm{~b}$ & $2.0 \mathrm{~b}$ & $0.6 \mathrm{~b}$ & $0.3 \mathrm{~b}$ & $10.6 \mathrm{~b}$ & $1.3 \mathrm{~b}$ & $21.5 b$ & $31.1 \mathrm{~b}$ & $2.5 \mathrm{~b}$ \\
\hline Average & 6.3 & 12.5 & 1.2 & 3.6 & 0.8 & 0.5 & 11.6 & 1.5 & 26.8 & 40.4 & 17.7 \\
\hline CV 1 (\%) & 9.2 & 17.1 & 12.3 & 46.6 & 12.5 & 12.3 & 14.9 & 21.6 & 30.1 & 28.7 & 79.5 \\
\hline CV 2 (\%) & 10.9 & 17.4 & 14.6 & 47.1 & 13.0 & 14.7 & 16.9 & 25.6 & 33.5 & 30.3 & 89.1 \\
\hline
\end{tabular}

Table 4. Average results of macro and micronutrients extraction in branches and clusters of 'Venus' grape vine grafted onto different rootstocks during two growing seasons.

\begin{tabular}{|c|c|c|c|c|c|}
\hline \multirow{2}{*}{ Rootstocks } & \multirow[b]{2}{*}{---- $\mathrm{g} \mathrm{kg}^{-1}$---- } & B & $\mathrm{Cu}$ & $\mathrm{Mn}$ & $\mathrm{Zn}$ \\
\hline & & \multicolumn{4}{|c|}{ mg kg ${ }^{-1}$ - } \\
\hline 'IAC 313' & $15 \mathrm{c}$ & $30 \mathrm{~b}$ & $22 \mathrm{~b}$ & $401 \mathrm{~b}$ & $54 \mathrm{c}$ \\
\hline 'IAC 572’ & $36 a$ & $53 \mathrm{a}$ & $48 \mathrm{a}$ & 649 a & $113 \mathrm{a}$ \\
\hline ‘IAC 571-6’ & $18 \mathrm{c}$ & $30 \mathrm{~b}$ & $32 \mathrm{ab}$ & $435 \mathrm{~b}$ & $69 \mathrm{bc}$ \\
\hline 'IAC 766’ & $26 \mathrm{~b}$ & $44 \mathrm{a}$ & $41 \mathrm{a}$ & $563 a b$ & $96 \mathrm{ab}$ \\
\hline \multicolumn{6}{|l|}{ Season } \\
\hline 2013 & 23 & $45 \mathrm{a}$ & $43 a$ & $475 \mathrm{~b}$ & $99 a$ \\
\hline 2014 & 24 & $33 \mathrm{~b}$ & $29 \mathrm{~b}$ & 549 a & $68 \mathrm{~b}$ \\
\hline Average & 23.8 & 39.2 & 35.6 & 512 & 83.2 \\
\hline CV 1 (\%) & 38.6 & 34.2 & 56.2 & 37.5 & 41.6 \\
\hline CV 2 (\%) & 24.4 & 27.8 & 42.2 & 21.9 & 35.1 \\
\hline
\end{tabular}


Table 5. Average results of macro and micronutrients extraction in branches and clusters of 'Venus' grape vine grafted onto different rootstocks during two growing seasons.

\begin{tabular}{|c|c|c|c|c|c|c|c|}
\hline \multirow{2}{*}{ Rootstocks } & \multirow{2}{*}{ Season } & K & $\mathbf{P}$ & $\mathrm{Ca}$ & $\mathrm{Mg}$ & $\mathbf{S}$ & \multirow{2}{*}{$\begin{array}{c}\text { Fe } \\
\mathrm{g} \mathrm{kg}^{-1}--\end{array}$} \\
\hline & & \multicolumn{5}{|c|}{ 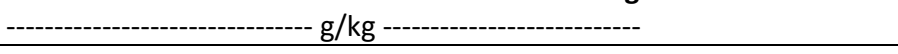 } & \\
\hline 'IAC 313' & 2013 & $28 \mathrm{Ba}$ & $3.0 \mathrm{Ba}$ & $13 \mathrm{Ba}$ & $3.2 \mathrm{Ba}$ & $1.6 \mathrm{Ba}$ & $95 \mathrm{Ba}$ \\
\hline 'IAC 572’ & 2013 & $57 \mathrm{Aa}$ & $5.4 \mathrm{Aa}$ & $19 \mathrm{Ba}$ & $5.2 \mathrm{Aa}$ & $3.1 \mathrm{Aa}$ & $190 \mathrm{Aa}$ \\
\hline 'IAC 571-6’ & 2013 & $22 \mathrm{Ba}$ & 3.2 Ba & $15 \mathrm{Ba}$ & $3.1 \mathrm{Ba}$ & 1.7 Ba & $124 \mathrm{Ba}$ \\
\hline 'IAC 766’ & 2013 & $19 \mathrm{Bb}$ & $7.1 \mathrm{Aa}$ & $33 \mathrm{Aa}$ & $5.8 \mathrm{Aa}$ & $3.0 \mathrm{Aa}$ & $204 \mathrm{Aa}$ \\
\hline 'IAC 313' & 2014 & $19 \mathrm{Ba}$ & $2.2 \mathrm{Ca}$ & $9 \mathrm{Ca}$ & $2.1 \mathrm{Ca}$ & $1.1 \mathrm{Ca}$ & $47 \mathrm{Bb}$ \\
\hline 'IAC 572’ & 2014 & $53 \mathrm{Aa}$ & $5.7 \mathrm{Aa}$ & $24 \mathrm{Aa}$ & $5.5 \mathrm{Aa}$ & $3.2 \mathrm{Aa}$ & $152 \mathrm{Aa}$ \\
\hline 'IAC 571-6’ & 2014 & $28 \mathrm{Ba}$ & $3.1 \mathrm{BCa}$ & $13 \mathrm{BCa}$ & $2.9 \mathrm{BCa}$ & $1.6 \mathrm{BCa}$ & $77 \mathrm{Bb}$ \\
\hline 'IAC 766’ & 2014 & $34 \mathrm{Ba}$ & $4.5 \mathrm{ABb}$ & $19 \mathrm{ABb}$ & $4.2 \mathrm{ABb}$ & $2.1 \mathrm{Bb}$ & $85 \mathrm{Bb}$ \\
\hline
\end{tabular}

'IAC 571-6' rootstocks. These data corroborate with those obtained by Tecchio et al. (2011), which obtained higher K content and lower $\mathrm{Ca}$ and $\mathrm{Zn}$ contents in 'Niagara Rosada' clusters grafted on 'IAC 572' rootstock. Tecchio et al. (2014) also reported that 'IAC 572' rootstock provided higher $\mathrm{K}$ and $\mathrm{Cu}$ contents and lower $\mathrm{Ca}, \mathrm{S}$ and Fe contents for 'Niagara Rosada' clusters. Differences related to nutrient content in branches and clusters of the other cultivars are due to rootstock variation that was also confirmed by Miele et al. (2009). The authors concluded that the variations obtained in nutrient contents of grape vine branches and clusters could be found to the genetics of rootstock and their vigor.

\section{Total nutrient removal by pruning branches and harvesting clusters}

For $\mathrm{N}, \mathrm{B}, \mathrm{Cu}, \mathrm{Mn}$ and $\mathrm{Zn}$, there was no significant interaction between rootstocks and growing seasons (Table 4). $\mathrm{N}$ was the only one in which there was no significant difference in the total extraction between growing seasons. Schreiner et al. (2006) assessed cv. Pinot Noir grapes in Oregon, USA, obtained values like those found in this study. The nutrient extraction through the clusters presented the following descending order: $\mathrm{K}>\mathrm{N}>\mathrm{Ca}>\mathrm{P}>\mathrm{Mg}>\mathrm{Fe}>\mathrm{B}>\mathrm{Mn}>\mathrm{Cu}>$ $\mathrm{Zn}$, with average values of $11.8,6.5,1.11,1.09,0.72 \mathrm{~g} \mathrm{Kg}^{-1}$ for macronutrients; and 36.5, 14.7, 14.2, 4.0, $4.0 \mathrm{mg} \mathrm{Kg}^{-1}$ for micronutrients, respectively.

The highest value of $\mathrm{N}$ was found in branches of 'Venus' grafted on 'IAC 572' rootstock and the lowest values were obtained in the associations of 'Venus' with 'IAC 313' and 'Venus' with 'IAC 571-6'. Tecchio et al. (2011) assessed nutrient extraction in 'Niagara Rosada' grafted onto different rootstocks, obtained the highest value of $\mathrm{N}$ in grape vines grafted on 'IAC 766 ' rootstock, although it did not differ from 'IAC 572' and 'IAC 571-6'.

Nitrogen fertilization stands out among several factors that may interfere in $\mathrm{N}$ content from soil extraction and grape vine tissues accumulation (Miele et al., 2009). However, $\mathrm{N}$ is lost by leaching into the soil, as nitrate, and to a lesser extent, ammonium, in vineyards (Barlow et al., 2009).

The cV. Venus grafted on 'IAC 572' rootstock extracted higher amounts of $\mathrm{B}, \mathrm{Cu}, \mathrm{Mn}$ and $\mathrm{Zn}$ (Table 4), although it did not differ significantly from 'IAC 766' rootstock. Regardless, $\mathrm{Cu}$ content did not differ from the values extracted in 'IAC $571-6$ ' rootstock. The following micronutrients $B, C u$ and $\mathrm{Zn}$ were extracted in higher quantity in the year of 2013,

different from $\mathrm{Mn}$ that was extracted in a smaller quantity in that same year (Table 4).

Albuquerque and Dechen (2000) assessed macronutrient absorption capacity in grape vine grafted on rootstocks, also obtained high nutrient accumulation in 'IAC 572' rootstock, extracting a larger amount of $\mathrm{N}, \mathrm{P}, \mathrm{K}$ and $\mathrm{Ca}$, differing significantly from 'IAC 313', 'IAC 766', 'Dog Ridge', 'Salt Creek' and 'Harmony' rootstocks. In 'Niagara Rosada' grape vines grafted onto 'IAC 313', 'IAC 572', 'IAC571-6', 'IAC 766' and '106-8 Mgt' rootstocks, we found no significant differences on the total extraction of $\mathrm{B}, \mathrm{Mn}$ and $\mathrm{Zn}$ micronutrients. Regarding to $\mathrm{Cu}$ and Fe contents, the highest export values were observed in grapevines grown onto 'IAC 572 ' and 'IAC 571-6' rootstocks; besides neither rootstocks differed in the content of Fe as '106-8 Mgt' (Tecchio et al., 2014).

There was a significant interaction between rootstocks and growing cycles with regards to total extraction of $\mathrm{K}, \mathrm{P}, \mathrm{Ca}$, $\mathrm{Mg}$ and $\mathrm{S}$ macronutrients, and Fe micronutrient (Table 5). In the year of 2013, grape vines grafted on 'IAC 766' rootstock performed the highest values of $\mathrm{P}, \mathrm{Ca}, \mathrm{Mg}$ and Fe extraction; however, it did not differ from the 'Venus'/ 'IAC 572' combination, except $\mathrm{Ca}$ values. In the same year, cv. Venus grafted on 'IAC 766 ' rootstock extracted more $\mathrm{K}$ and $\mathrm{S}$, although it did not differ from 'IAC 766 ' rootstock for $S$ values. In 2014, 'IAC 572' rootstock provided an increased in $\mathrm{K}, \mathrm{P}, \mathrm{Ca}, \mathrm{Mg}, \mathrm{S}$ and Fe extraction, not significantly different from 'Venus'/ 'IAC 766' for P, Ca and Mg. During both seasons, 'IAC 572 ' and 'IAC 766' rootstocks extracted more of these nutrients compared to 'IAC 313' and 'IAC 571-6' rootstocks.

There was no significant difference between growing seasons when we assessed the total macronutrients extraction in 'IAC 313', 'IAC 572' and 'IAC 571-6' rootstocks. However, 'IAC 766' rootstock extracted a larger amount of $P$, $\mathrm{Ca}, \mathrm{Mg}$ and $\mathrm{S}$ and a smaller quantity of $\mathrm{K}$ in 2013.

$\mathrm{K}$ plays a vital process in all grape cycle phases. $\mathrm{K}$ is the most extracted and accumulated nutrient in these plants. This increase is mainly influenced by the concentration and availability of this nutrient in soil, in addition to potassium fertilization (Ryser et al., 1989; Zamboni and lacono, 1989). The rootstock may directly interfere on the $\mathrm{pH}$ of grape juice (Whiting, 2003) and interactions between ions (Ahn et al., 2004).

In Louveira, state of Sao Paulo, a study showed no significant interaction for total nutrient extraction in 'Niagara Rosada' grape vines grafted onto different rootstocks during three growing seasons (Tecchio et al., 2014). These authors verified higher nutrient extraction for 'IAC 572' rootstock compared to 'IAC 313', 'IAC 571-6', 'IAC 766' and '106-8 Mgt' rootstocks.

For total nutrients extraction removed in branches and clusters, we observed a descending order of $\mathrm{K}>\mathrm{N}>\mathrm{Ca}>\mathrm{P}>$ $\mathrm{Mg}>\mathrm{S}>\mathrm{Mn}>\mathrm{Fe}>\mathrm{Zn}>\mathrm{B}>\mathrm{Cu}$. In parts, these results corroborate to those obtained by Giovannini et al. (2001) and Tecchio et al. (2011), which obtained the following descending order: $\mathrm{K}>\mathrm{N}>\mathrm{Ca}>\mathrm{P}>\mathrm{Mg}>\mathrm{S}>\mathrm{Mn}>\mathrm{Fe}>\mathrm{Zn}>\mathrm{B}$ $>\mathrm{Cu}$ and $\mathrm{K}>\mathrm{N}>\mathrm{Ca}>\mathrm{P}>\mathrm{Mg}>\mathrm{S}>\mathrm{Mn}>\mathrm{Fe}>\mathrm{Zn}>\mathrm{B}>\mathrm{Cu}$, 
respectively. It was noticed that there was only a difference in the micronutrients order, probably due to agricultural pesticides and foliar fertilizers application that contained micronutrients, as well as soil chemical characteristics in the growing areas. In 'Isabel Precoce' grape vines grafted on 'VR 043-43' rootstock, the descending order confirms this study data for macronutrients. However, 'Paulsen 1103' rootstock, reversed $\mathrm{P}$ and $\mathrm{Ca}$ positions, resulting in the following descending order of $\mathrm{K}>\mathrm{N}>\mathrm{P}>\mathrm{Ca}>\mathrm{Mg}$ (Sato et al., 2016). In the current study, it was observed that the average values obtained from total nutrient extraction in branches and clusters of 'Venus' grape vines were lower than those obtained by Tecchio et al. (2011) in 'Niagara Rosada' grape vines, which obtained average amounts of $47 \mathrm{~kg} \mathrm{ha}^{-1} \mathrm{~N}, 84 \mathrm{~kg}$ $\mathrm{ha}^{-1} \mathrm{~K}, 8.4 \mathrm{~kg} \mathrm{ha}^{-1} \mathrm{P}, 20 \mathrm{~kg} \mathrm{ha}^{-1} \mathrm{Mg}, 6.3 \mathrm{~kg} \mathrm{ha}^{-1} \mathrm{Ca}$ and $4.4 \mathrm{~kg}$ $\mathrm{ha}^{-1} \mathrm{~S}$ and $70 \mathrm{~g} \mathrm{ha}^{-1} \mathrm{~B}, 23 \mathrm{~g} \mathrm{ha}^{-1} \mathrm{Cu}, 215 \mathrm{~g}^{-1} \mathrm{Fe}, 81 \mathrm{~g}^{-1} \mathrm{Mn}$ and $108 \mathrm{~g}$ ha-1 $\mathrm{Zn}$; showing that 'Venus' grape vine has low nutritional requirements.

\section{Materials and methods}

\section{Experimental location and growing conditions}

We performed the experiment at the Advanced Technological Research Centre for Rubber Agribusiness and Agroforestry Systems of the Agronomic Institute of Campinas (IAC) in Votuporanga (20015'S and 5030'O) in the state of São Paulo, Brazil. According to Köppen classification, climate is type $A w$, with an annual average temperature of $24.3^{\circ} \mathrm{C}$ and average precipitation of $1,449 \mathrm{~mm}$, mostly concentrated from October to March (Cepagri, 2017). According to Embrapa (1999), the soil type is Red Yellow Argisol.

The experiment was established in October 2011, when rootstocks were planted, and scions were grafted in July 2012. The $2.0 \times 2.0 \mathrm{~m}$ spacing supported by pergola system was used in the vineyards, besides that micro-sprinklers were intended to provide irrigation. Crop pruning was performed, leaving 6 to 8 buds per stem on August $4^{\text {th }}, 2013$ and July 25th, 2014 . Harvesting was done in November 2013 and 2014.

\section{Treatments and experimental design}

The treatments consisted on the combination of the 'Venus' grape vine (a hybrid reported as Alden x NY46000 cross) grafted onto the rootstocks IAC 766 'Campinas' (106-8 Mgt x Vitis caribaea), IAC 572 'Jales' (V. caribaea x RR 101-14 Mgt), IAC 313 'Tropical' (Golia x V. cinerea) and IAC 571-6 'Jundiaí' (V. caribaea $x$ Pirovano 57).

The whole plot treatments were arranged in a randomized complete block design, subdivided in plots, with 10 replicates and four plants per plot; the plots represented by rootstocks and subplots by growing years.

\section{Samples and measurements}

After pruning, two branches per plant were sampled, which were taken to laboratory and subjected to washing and drying in a heated oven provided with forced air circulation. Subsequently, we analyzed the samples for $\mathrm{N}, \mathrm{P}, \mathrm{K}, \mathrm{Ca}, \mathrm{Mg}$, $\mathrm{S}, \mathrm{B}, \mathrm{Cu}, \mathrm{Fe}, \mathrm{Mn}$ and $\mathrm{Zn}$ contents within the branch's nutrients. Thus, branch dry mass was estimated by nutrients export through the removal of the pruned branches in each experimental plot. To determine yield, the average yield per plant of each plot was multiplied by the number of plants per hectare, results were expressed in terms of $t \mathrm{ha}^{-1}$. At harvesting, ten clusters per experimental plot were sampled and submitted to washing and drying procedure in a heated oven provided with forced air circulation at a temperature of 75 and $85 \circ \mathrm{C}$ for 10 days, to obtain dry mass percentage. Subsequently, milling was performed for chemical analysis of macro and micronutrients. In clusters, nutrient extraction was obtained by multiplying the nutrient content by the total dry mass of the clusters harvested from each experimental plot. The nutrients in branches and clusters were determined, according to the methodology described by Malavolta et al. (1997). The total nutrient extraction was obtained summing the nutrient extraction through branches and clusters.

\section{Statistical analysis}

We submitted the data to analysis of variance and the averages were compared by the Tukey test at $5 \%$ of significance.

\section{Conclusion}

'IAC 572' and 'IAC 766' rootstocks provided greater nutrient uptake in pruned branches and harvested clusters of 'Venus' grape vines. Total removal uptake by pruning branches and harvesting clusters showed the following descending order of $\mathrm{K}>\mathrm{N}>\mathrm{Ca}>\mathrm{P}>\mathrm{Mg}>\mathrm{S}>\mathrm{Mn}>\mathrm{Fe}>\mathrm{Zn}>\mathrm{B}>\mathrm{Cu}$.

\section{Acknowledgements}

This work was supported by the Fundação de Amparo à Pesquisa do Estado de São Paulo (FAPESP, process $n^{\circ}$ 2011/03440-6). The authors are grateful to Conselho Nacional de Desenvolvimento Científico e Tecnológico (CNPQ, grant number 305724/2018-5), Coordenação de Aperfeiçoamento de Pessoal de Nível Superior (CAPES) and Centro Avançado de Pesquisa Tecnológica do Agronegócio de Seringueira e Sistemas Agroflorestais for the availability of the experimental area where this work was performed.

\section{References}

Agrianual (2018) Uva: produção brasileira. Anuário da agricultura brasileira. São Paulo.

Ahn SJ, Shin R, Schachtman DP (2004) Expression of KT/KUP genes in Arabidopsis and the role of root hairs in $\mathrm{k}+$ uptake. Plant Physiol. 134(3):1135-1145.

Albuquerque TCS, Dechen AR (2000) Absorção de macronutrientes por porta-enxertos e cultivares de videira em hidroponia. Sci Agric. 57(1):135-139.

Barlow K, Bond W, Holzapfel B, Smith J, Hutton R (2009) Nitrogen concentrations in soil solution and surface runoff on irrigated vineyards in Austrália. Aust J Grape Wine Res. 15(2):131-143.

Bavaresco L, Luvisolo C (2000) Effect of grafting on grapevine chlorosis and hydraulic conductivity. Vitis. 39(3):89-92.

Bettoni JC. Gardini, JPP, Schumacher RL, Rodrigues OT, Souza JA (2013) Qualidade físico-química, extração e exportação de nutrientes da cultivar Cabernet Sauvignon sobre dois porta-enxertos. Ignis, Caçador. 2(1):41-53.

Billones-Baaijens R, Jones EE, Ridgway HJ, Jaspers MV (2014) Susceptibility of common rootstock and scion varieties of grapevines to Botryosphaeriaceae species. Australas Plant Pathol. 43(1):25-31 
Camargo UA, Mandelli $F$ (1993) Vênus: uva precoce para mesa. Comunicado técnico Embrapa uva e vinho. 13:1-4.

Cepagri (2017) Clima dos municípios paulistas. Available in <http://www.cpa.unicamp.br/outras-informacoes/climados-municipios-paulistas.html>. Accessed in: 18 jan. 2017.

Cookson SJ, Ollat N (2013) Grafting with rootstocks induces extensive transcriptional reprogramming in the shoot apical meristem of grapevine. BMC Plant Biol. 13(1):p.147.

Embrapa - Empresa Brasileira de Pesquisa Agropecuária (1999) Sistema brasileiro de classificação de solos. Rio de Janeiro: CNPS.

Faria CMB, Silva DJ, Pereira JR (2004) Avaliação nutricional da videira no submédio São Francisco. Boletim de Pesquisa e Desenvolvimento. 61, 20 p.

Giovannini E, Mieli A, Fráguas JC, Barradas CIN (2001) Extração de nutrientes pela videira cv. Cabernet Sauvignon na Serra Gaúcha. Pesqui Agropec Gaúcha. 7(1):27-40.

Heim G, Landsberg JJ, Watson RL, Brain P (1979) Ecophysiology of apple trees: Dry matter production and partitioning by young 'Golden Delicious' trees in France and England. J Applied Ecol. 16(1):179-194.

IEA - Instituto de Economia Agrícola (2017) Estatísticas da produção paulista. Retrieved January 29, 2017. Available in http://www.iea.sp.gov.br/out/index.php. Acessed in: 29 jan. 2017

Jogaiah S, Oulkar DP, Banerjee K, Sharma J, Patil AG, Maske SR, Somkuwar RG (2013) Biochemically induced variations during some phenological stages in 'Thompson Seedless' grapevines grafted on different rootstocks. S Afr J Enol Vitic. 34(1):36-45.

Jogaiah S, Ramteke SD, Sharma J, Upadhyay AK (2014) Moisture and salinity stress induced changes in biochemical constituents and water relations of different grape rootstock cultivars, Int J Agron. 2014:1-8.

Malavolta E, Vitti GC, Oliveira SA (1997) Avaliação do estado nutricional de plantas: princípios e aplicações. Potafos. 2:319 p.

Miele A, Rizzon LA, Giovannini E (2009) Efeito do portaenxerto no teor de nutrientes em tecidos da videira 'Cabernet Sauvignon'. Rev Bras de Frutic. 31(4):11411149.

Mota RV, Souza CR, Favero AC, Silva CPC, Carmo EL, Fonseca AL, Regina MA (2009) Produtividade e composição físicoquímica de bagas de cultivares de uva em distintos portaenxertos. Pesqui Agropec Bras. Brasília. 44(6):576-582.

Murolo S, Romanazzi G (2014) Effects of grapevine cultivar, rootstock and clone on esca disease. Australas Plant Pathol. 43(2):215-221.

Pauletto D; Mourão Filho FAA, Kluge RA, Scarpare Filho JA (2001) Produção e vigor da videira 'Niagara Rosada' relacionados com o porta-enxerto. Pesq Agropec Bras. (36)1:115-121.

Rizk-Alla MS, Sabry GH, Abd El-Wahab MA (2011) Influence of some rootstocks on the performance of Red Globe grape cultivar. J Am Sci. 7(4):71-81.
Rosecrance RC, Weinbaum SA, Brown PH (1996) Assessment of nitrogen, phoshporus and potassium uptake capacity and root growth in mature alternate - bearing pistachio (Pistacia vera) trees. Tree Physiol. 16:949-956

Ryser JP, Aerny J, Murisier F (1989) Fumure potassique de la vigne et acidité du vin. Rev Suisse Vitic Arboric Hortic. 21(5):319-323.

Sato AJ, Botelho RV, Broetto D, Marchi T, Oliari ICR (2016) Immobilization and nutrient uptake in 'early isabella' grapevines grafted on different rootstocks in organic management. Semin Ciênci Agrárias. 37(3):1201-1208.

Schreiner RP, Scagel CF, Baham J. (2006) Nutrient uptake and distribution in a mature 'Pinot Noir' vineyard. HortScience. 41(2):336-345.

Serra IA, Strever A, Myburgh PA, Deloire A (2014) Review: the interaction between rootstocks and cultivars (Vitis vinifera L.) to enhance drought tolerance in grapevine. Aust J Grape Wine Res. 20(1):1-14.

Tecchio MA, Moura MF, Pires EJP, Terra MM (2013) Efeito do porta-enxerto e da época de poda na duração das fases fenológicas e no acúmulo de graus-dia pela videira 'Niagara Rosada. Rev Bras Frutic. 35(4):1073-1080.

Tecchio MA, Moura MF, Teixeira LAJ, Pires EJP, Leonel S (2014) Influence of rootstocks and pruning times on yield and on nutrient content and extraction in 'Niagara Rosada' grapevine. Pesqui Agropec Bras. 49(5):340-348.

Tecchio MA, Pires EJP, Terra MM, Teixeira LAJ, Leonel S (2007) Características físicas e acúmulo de nutrientes pelos cachos de 'Niagara Rosada' em vinhedos na região de Jundiaí. Rev Bras Frutic. 29(3):621-625.

Tecchio MA, Teixeira LAJ, Terra MM, Moura MF, Pires EJP (2011) Extração de nutrientes pela videira 'Niagara Rosada' enxertada em diferentes porta-enxertos. Rev Bras Frutic. 33:736-742.

Terra MM, Pires EJP, Pommer CV, Botelho RV (2003) Produtividade da cultivar de uva de mesa Niagara Rosada sobre diferentes porta-enxertos, em Monte Alegre do SulSP. Rev Bras Frutic. 25(3):549-551.

Tofanelli MBD, Botelho RV, Pires EJP, Vilela LAF, Ribeiro DO (2011) Phenology of 'Niagara Rosada' grapevines grafted on different rootstocks grown on Cerrado (Brazilian savanna) of Goiás State, Brazil. African J Biotechnol. 10(17):3387-3392.

Weinbaum SA (2001) Necessity for whole tree excavations in determining patterns and magnitude of macronutrient uptake by mature deciduous fruit trees. Acta Hortic. 564(1):41-49.

Weinbaum SA, Niederholzer FJA, Ponchner S, Rosecrance RC, Carlson RM, Whittlesey AC, Muraoka TT (1994). Nutrient uptake by cropping and defruited field-grown 'Frendi' prune trees. J Amer Soc Hort Sci. 119:925-938.

Whiting JR (2003) Selection of grapevine rootstocks and clones for greater Victoria. Department of Primary Industries, Australia. 40p.

Zamboni M, lacono F (1989) Influenza dell'interazione tra concimazione potassica, portainnesto e terreno sulle caratteristiche del mosto di viti allevate in vaso. Vignevini. 16(9):37-41. 